\title{
Experimental Study on Manufacturing Artificial Aggregate from Various Industrial Waste and Its Applications in Concrete - A Critical Review
}

\author{
S.Gunasekar $^{1 *}$, L.Santhosh ${ }^{2}$, P. Ragupathi ${ }^{2}$ \\ ${ }^{1}$ Assistant Professor, Department Of Civil Engineering, K.S.Rangasamy College of Technology, Tiruchengode - \\ 637215,Tamil Nadu, India. \\ ${ }^{2}$ UG Scholar, Department Of Civil Engineering, K.S.Rangasamy College of Technology, Tiruchengode - 637215.
}

Tamil Nadu, India.

*Corresponding author E-Mail ID: guna.skr87@gmail.com

Doi: https://doi.org/10.34256/irjmtcon66

\begin{abstract}
The aim of this paper is to examine the production of artificial aggregate and its potential applications in concrete. The waste materials from industrial are one of the concern issues in sustainable development. Recycle and reuse these waste materials is one of the strategies to produce the better sustainable system. One of the methods is by using the waste materials to produce artificial aggregate by palatalization. There are wide applications of artificial aggregate, for instance construction, agriculture, geotechnical fill, waste water, drainage and many more. Physical properties such as bulk density, specific gravity, unit weight, porosity and water absorption are important criteria. The performance of the artificial aggregate varies, depending on the application.
\end{abstract}

Keywords: Industrial Waste management, artificial aggregate, Concrete, Aggregate Replacement, Strength Properties.

\section{INTRODUCTION}

Lightweight concrete has been used as building material for many decades throughout the world, especially in the countries like United States, Japan and Europe. The application ranges from lightweight partitions, walls and secondary structural components to the primary structural components. These concrete are either foamed type concrete or no fines, lightweight aggregates concrete.

Pelletization is a well-known technique in the metallurgical industry but has not been widely used in the construction industry. Lightweight aggregate can be produced by nodulizing the fly ash in a pelletizer with a proportionate quantity of water, and further hardened by adopting sintering, cold bonding or autoclaving.

When a fine-grained material is moisturized, a thin liquid film develops on the surface of each grain. When the moisturized particles contact each other bridges are formed at points of contact and bonding forces develop gradually when these particles are rotated into balls. Pellets attain strength by mechanical forces, which are produced when the balls bump against each other and against the walls of the pelletizer. Artificial aggregates can be manufactured by means of two types of processes: cement-based granulation and high temperature sintering. 


\section{OBJECTIVES}

- The main objectives of this work are to encourage researchers to reduce and reuse of industrial wastes in concrete construction.

- Reduction and utilization of industrial waste into masonry and concrete construction.

\section{LITERATURE REVIEW}

1. G.Decasa, et.al., experimented a study on Production of artificial aggrergate from ceramic processing of municipal incinerator fly ash. From the experimental study it was concluded that Municipal solid waste incinerator fly ash was processed to form new ceramic materials using conventional processing technology. The findings are:

- Density of product is $2.65-2.80 \mathrm{~g} / \mathrm{cm}^{3}$

- Compressive strength is $260-450 \mathrm{~N} / \mathrm{mm}^{2}$

- Water absorption is $0.1-0.2 \%$

2. Jercy witek et.al., conducted an experiment on Obtain artificial aggregate from the cement asbestos by the melting technique in an Arc - Resistance Furnace. In that project, the recycling techniques, which allow the re-use of neutralized asbestos waste, instead of disposing in special landfills. Obtaining aggregate from asbestos waste by the fusion process in the electric arc - resistance process. The mixtures of asbestos - containing material with selected fluxes were melted and the cast into grain of aggregate.

- Density $=3.18-3.20 \mathrm{~kg} / \mathrm{m}^{3}$

- Water absorption $=5-10 \%$

- $\quad$ Flakiness index $=18+2 \%$

3. Srinivasan K et.el., conducted a test on An experimental study on manufacture of artificial aggregate incorporating fly ash, Rice husk ash and iron ore dust. From his observation, Fly ash and rice husk ash is found to be greater to other supplementary materials like silica fume. Due to its high pozzolanic activity, both strength and durability of concrete are enriched. $1 \mathrm{~kg}$ of the cementious mixture requires $250 \mathrm{ml}$ of portable water to form homogeneous mixture.

- $\quad$ Density of product $=2151 \mathrm{~kg} / \mathrm{m} 3$

4. Kilincarslan.S investigated on Investigation of heavy concretes produced with heavy artificial aggregates. The results are Heavy weight concrete is most commonly used for radiation shielding etc. Artificial aggregate such as industrial residues like iron and lead particles. The waste products of metal industry are mostly used for heavy aggregates. The linear attenuation coefficients were determined by measuring the transmission of gamma-rays through the target of $2.4 \mathrm{~cm}$ and $4.8 \mathrm{~cm}$.

5. Harikrishnan K.I and K Ramamurthy experimented that, Influence of pelletization process on the properties of fly ash aggregate. In this research work, Influences of parameters are i) Speed of revolution of pelletizer disc, ii) Angle of pelletizer disc iii) Moisture content iv) Duration of pelletization. Fractional factorial experiments using the concept of Tauguchi's orthogonal array is used in this study.

6. Harilal B and Job Thomas conducted a test on Concrete made using cold bonded artificial aggregate. The findings are, the aggregate are manufactured through polarization method in different proportion of fly ash and quarry dust with ordinary Portland cement as binder. The compaction factor is greater than 0.8. Compressive strength $=35 \mathrm{mpa}$. Porosity $=1.2-1.5$. 
7. Francesco colangelo, Francesco messina, Raffaelo cioffi conducted Recycling of MSWI fly ash by means of compendious double step cold bonding Pelletization technology assessment for production of light weight artificial aggregate. The results are, recycling of municipal solid waste incinerator fly ash by means of cold bonding pelletization. Cement, lime and fly ash as a binding system.

- Density $=1000-1600 \mathrm{~kg} / \mathrm{m}^{3}$

- Water absorption $=7-16 \%$

- $\quad$ Crushing strength $=1.3-6.2 \mathrm{mpa}$

8. Hardjito D. et,al. experimented that the Development of volcanic mud - based geo polymer artificial aggregate. In his experiment, the mud is used after pre-treatment in the form of calcinations and grinding, the volcanic mud is found to be reactive. Geo polymerization is performed by mixing the more amorphous form of the volcanic mud with high alkaline solution, followed by curing in an elevated temperature.

- $\quad$ Specific gravity $=1470-1800 \mathrm{~kg} / \mathrm{m}^{3}$

9. Wasan Khalil et.al. experimented that the behaviour of high performance artificial light weight aggregate concrete reinforced with hybrid fibers. In high performance lightweight concrete containing artificial aggregate containing artificial aggregate as coarse light weight aggregate and reinforced with mono fiber, double and triple hybrid fibers in different aspects ratios.

- $\quad$ Compressive strength $=34-69 \mathrm{mpa}$

- Air dry density not more than $2000 \mathrm{~kg} / \mathrm{m}^{3}$

10. Strokova V. et.al. completed an experiment on Artificial aggregate based on granulated reactive silica powder. In his research, the results findings are the development of artificial aggregate based on granulated reactive silica powder materials activated by alkaline components. The alkali content was optimized depending upon the properties of reactive silica material. The reactive silica was determined to maximize the volume of synthesized soluble polysilicates. The alkali content can vary from $10-30 \%$.

11. Francesco colangelo et.al. completed an experiment on Artificial aggregate production from power plant solid waste by means of a granulation process. The preparation of artificial aggregate by means of a granulator equipped with a rotating and tilting plate. The waste employed as weathered coal fly ash, waste water treatment sludge and desulphurization device sludge. Hydraulic lime added for commercial binder.

- Density $=1370-1490 \mathrm{~kg} / \mathrm{m} 3$

12. KwekS Y.\& H Awang experimented on Artificial light weight aggregate from palm oil fuel ash and water treatment waste. The artificial aggregate containing palm oil fuel ash, silt from water treatment sludge. Alkaline activator and lime water were added $5-25 \%$ to binder.

- $\quad$ Specific gravity $=1.42-1.51$

- Compressive strength $=8.11 \mathrm{mpa}$

- Water absorption $=1.66 \%$

13. Vit cerny and Rostislaw Drochytka completed an experiment on artificial aggregate from sintered coal ash. In his research work Micro silica, Fe2O3 and fly ash body, the three samples of high temperature lignite combustion fly ash were selected for the preparation of artificial aggregate. The addition of $\mathrm{Fe} 2 \mathrm{O} 3$ did not take place in melting process. It helps to weaken the fly ash body's structure. 
14. Mehmet gesoylu et. al. completed a work on Recycling ground granulated blast furnace slag as cold bonded artificial aggregate partially used in self-compacting concrete. Ground granulated blast furnace slag; a by-product from iron industry was recycled as artificial aggregate through cold bonding palletisation process. Artificial slag aggregate replaced partially the natural coarse aggregate in the production of self-compacting concrete.

15. Erhan guneyis et.al. Completed a research work on Influencing of the artificial light weight aggregate on fresh properties and compressive strength of the self-compacting mortars. In his work, the artificial aggregate used in this study were manufactured through cold bonding pelletization of fly ash and Portland cement. The self-compacting mortars were designed to flow binder content of $540 \mathrm{~kg} / \mathrm{m} 3,520 \mathrm{~kg} / \mathrm{m} 3,500 \mathrm{~kg} / \mathrm{m} 3 \& 480 \mathrm{~kg} / \mathrm{m} 3$ at found water to binder ratio of $0.33,0.37,0.4,0.44$. At each water-to-binder ratio, the artificial light weight aggregate at replacement level of $0 \%, 20 \%, 40 \%$, and $60 \%$.

\section{CONCLUSIONS}

From these journals we have learnt about various materials used for the manufacturing of paver blocks. Then the properties and strength of these materials used in the journals were studied. The waste materials like waste marbles, fly ash, coal waste, polyethylene, electroplating waste, mineral waste, etc.... are studied for the strength properties. Various properties like compressive strength, flexural strength, water absorption, abrasion resistance of paver blocks made with different materials are studied from these journals.

After the completion of all the tests, it was observed that the mechanical properties of paver blocks, cubes and cylinders were increased with the addition of construction and demolition (C\&D) waste. The micro structural properties like water absorption for paver blocks were also identified.

\section{REFERENCES}

1. Erhan Güneyisi, Mehmet Gesoglu, Hussein Ghanim, Süleyman _Ipek, Ihsan Taha,(2016), "Influence of the artificial lightweight aggregate on fresh propertiesand compressive strength of the self-compacting mortars", Construction and Building Materials, Vol: 116,2016, pp: $151-158$.

2. Vit Cerny, Rostislav Drochytka, "Artificial Aggregate From Sintered Coal AshUmetni Agregat Iz Sintranega Pepela Premoga",Materials and technology, MTAEC9, 50(5)749(2016).

3. D. Hardjito1, Antoni1, E. Suryawangil and Y. Takarendehang, "Development of Volcanic Mud-Based GeopolymerArtificial Aggregate”, Conference Paper · August 2013.

4. Francesco Colangeloa, Francesco Messinaa, Raffaele Cioffia, "Recycling of MSWI fly ash by means of cementitious double step coldbonding pelletization: Technological assessment for the production oflightweight artificial aggregates", Journal of Hazardous Materials, Vol: 299, (2015), pp: 181-191.

5. WasanKhalil1,Hisham Ahmed1, andZainabHussein, "Behavior of high performance artificial lightweight aggregate concrete reinforced with hybrid fibers", MATEC Web of Conferences · January 2018.

6. S Y Kwek and H Awang, "Artificial lightweight aggregate from palm oil fuel ash (POFA)and water treatment waste", 14th International Conference on Concrete Engineering and Technology, IOP Conf. Series: Materials Science and Engineering 431 (2018) 082005.

7. Harilal B. and Job Thomas , "Concrete made using cold bonded artificial aggregate", American Journal of Engineering Research (AJER) e-ISSN : 2320-0847 p-ISSN : 2320-0936 Volume-1 pp-20-25. 
8. K.I. Harikrishnan, K. Ramamurthy, "Influence of pelletization process on the properties of fly ash aggregates", Waste Management, Vol: 26 (2006), pp:846-852.

9. S. Kilınçarslan, "Investigation of Heavy Concretes Producedwith Heavy Artificial Aggregates", Special issue of the International Conference on Computational and Experimental Science and Engineering (ICCESEN 2014).

10. G. De Casa, T. Mangialardi \& L. Piga, "Production of artificial aggregates fromceramic processing of municipalincinerator fly ash", International Journal of Environment and Waste Management · January 2004.

11. JerzyWitek, Bronisław Psiuk, Zdzisław Naziemiec and Robert Kusiorowski, "Obtaining an Artificial Aggregate fromCement-AsbestosWaste by the Melting Technique inan ArcResistance Furnace", Fibers, 2019, Vol: 7, Issue :10.

12. Srinivasan.K, Mutharasi.M, Vaishnavi.R, Sajin Mohan, Logeswaran.V, “An Experimental Study on Manufacture of

13. Artificial Aggregates Incorporating Flyash, RiceHusk Ash and Iron Ore Dust”, International Journal of Science, Engineering and Technology Research (IJSETR), Volume 5, Issue 1, January 2016.

14. V. Strokova, I. Zhernovsky, Y. Ogurtsova, A. Maksakov, M. Kozhukhova,K.Sobolev, "Artificial aggregates based on granulated reactive silica powders", Advanced Powder Technology · May 2014.

15. Mehmet Geso־glu*, Erhan Güneyisi, Swara Fuad Mahmood, Hatice Öznur Öz, Kasım Mermerdas, "Recycling ground granulated blast furnace slag as cold bonded artificial aggregatepartially used in self-compacting concrete", Journal of Hazardous Materials, Vol: 235-236, (2012), pp: 352-358. 